\title{
Investigating the factors affecting the development of the humanitarian aid supply chain by popular athletes
}

\section{Investigar los factores que afectan el desarrollo de la cadena de suministro de ayuda humanitaria por parte de los deportistas populares}

\author{
Yeganeh Gheibi \\ PhD Student in Sports Management, Kermanshah Branch, Islamic Azad University, \\ Kermanshah, Iran \\ ORCID: https://orcid.org/0000-0003-2309-6984
}

\author{
Shahab Bahrami \\ Assistant Professor, Department of Sports Management, Kermanshah Branch, Islamic Azad \\ University, Kermanshah, Iran \\ ORCID: https://orcid.org/0000-0002-6268-5012
}

Mohsen Bagherian Farahabadi (D)

Assistant Professor, Department of Sports Management, Faculty of Literature, Humanities and

Social Sciences, Sciences and Research Branch, Islamic Azad University, Tehran, Iran

ORCID: https://orcid.org/0000-0001-8653-3630

*Correspondence

Email: Bahramishahab2020@gmail.com
Cite as:

Gheibi, Y., Bahrami, SH., \& Bagherian Farahabadi, M (2021). Investigating the factors affecting the development of the humanitarian aid supply chain by popular athletes. Propósitos y Representaciones, 9 (SPE2), e954. Doi: http://dx.doi.org/10.20511/pyr2021.v9nSPE2.954 


\section{Summary}

The present study was designed and conducted to investigate the factors affecting the development of the humanitarian aid supply chain by popular athletes. The present study is one of the mixed researches which were done in the form of qualitative and quantitative methods. The statistical population of the present study in the qualitative section includes elites and experts in the field of the humanitarian supply chain, sports sociology, sports management, and crisis management. According to the purposeful selection, 13 people were identified as the research sample. In the quantitative part of the present study, in addition to the elites in the field of the humanitarian supply chain, sports sociology, sports management, and crisis management, some experts of the Crisis Management Organization and popular athletes were added to the statistical community. The collection tools of the present study included a semi-structured interview and a researcher-made questionnaire. In the quantitative analysis of the research, the structural equation method with the PLS approach has been used. The results of the present study showed that; 25 micro actives were extracted through interviews, these factors were divided into 5 categories: cultural, managerial, legal, human, and communication-technological factors. The research results showed that; among the factors affecting the development of the humanitarian aid supply chain through popular athletes, managerial factors had the most role and importance (impact $=0.983$; T-factor $=427.756$ ). This highlights the importance and necessity of management platforms for the development of the humanitarian aid supply chain through popular athletes.

Keywords: Supply Chain, Athletes, Humanitarian, Popularity

\section{Resumen}

El presente estudio fue diseñado y realizado para investigar los factores que afectan el desarrollo de la cadena de suministro de ayuda humanitaria por parte de los deportistas populares. El presente estudio es una de las investigaciones mixtas que se realizaron en forma de métodos cualitativos y cuantitativos. La población estadística del presente estudio en la sección cualitativa incluye élites y expertos en el campo de la cadena de suministro humanitaria, sociología deportiva, gestión deportiva y gestión de crisis. Según la selección intencionada, se identificaron 13 personas como muestra de investigación. En la parte cuantitativa del presente estudio, además de las élites en el campo de la cadena de suministro humanitario, sociología deportiva, gestión deportiva y gestión de crisis, se sumaron a la comunidad estadística algunos expertos de la Organización de Gestión de Crisis y deportistas populares. Las herramientas de recopilación del presente estudio incluyeron una entrevista semiestructurada y un cuestionario elaborado por el investigador. En el análisis cuantitativo de la investigación se ha utilizado el método de ecuaciones estructurales con el enfoque PLS. Los resultados del presente estudio mostraron que; A través de entrevistas se extrajeron 25 microactivos, estos factores se dividieron en 5 categorías: culturales, gerenciales, legales, humanos y comunicacionaltecnológicos. Los resultados de la investigación mostraron que; Entre los factores que afectan el desarrollo de la cadena de suministro de ayuda humanitaria a través de los deportistas populares, los factores de gestión tuvieron el mayor papel e importancia (impacto $=0,983$; factor $\mathrm{T}=$ 427,756). Esto resalta la importancia y necesidad de plataformas de gestión para el desarrollo de la cadena de suministro de ayuda humanitaria a través de deportistas populares.

Palabras clave: cadena de suministro, deportistas, humanitario, popularidad. 


\section{Introduction}

Today, compared to the past, we are witnessing natural and human disasters such as earthquakes, floods, volcanic eruptions, etc. Due to their special nature, disasters have many destructive effects on the lives of the inhabitants of the earth; The extent and severity of these effects are such that it has attracted a great deal of attention at the national and international levels to deal with these catastrophes. Therefore, humanitarian supply chain management before, during, and after the accident is of particular importance. In this regard, the need to identify and determine the dimensions and performance indicators to evaluate the performance of the humanitarian supply chain is strongly felt (Barani et al., 2017).

Every year, natural disasters such as earthquakes, floods, fires, hurricanes, and droughts affect different parts of the world. These natural disasters are often associated with damage to human life and property (Gupta et al., 2017). Given that the severity and dimensions of these incidents are often wide, as well as the impact of factors such as population growth, climate change, systems integration, the volume of demand for rescue operations is very high; Therefore, it is predicted that; Current aid and relief centers that normally meet the needs of the city are often insufficient to meet the demand created promptly (Jahre, 2017). Caring for the injured, sending essential goods and providing first aid, and transferring the injured to relief centers promptly is very important in reducing casualties and disabilities caused by these accidents (Seifert et al., 2018).

Supply chain management includes all activities that are used to connect suppliers, manufacturers, distributors, and customers, to produce and distribute goods in the right amount and at the right time with the least system costs and maximizing the level of customer service (Cozzolino, 2012). A humanitarian supply chain is a special type of supply chain with unique features that distinguish it from a commercial supply chain. The performance of this supply chain in disasters has a very important role in dealing with controlling and reducing the effects of disasters (Schulz \& Heigh., 2009).

Providing relief items needed in critical situations is a time-consuming and complex issue due to uncertainty in demand and the severity of the disaster. The humanitarian supply chain can solve this complexity (Ghasemian et al., 2017). The humanitarian supply chain in the academic literature refers to the process of planning, implementing, and effectively controlling the flow of costs and information and storing the required goods and materials from the point of origin to consumption. So its main purpose is to reduce and alleviate the suffering of people affected by the accident (Cabra et al., 2015). Thus, in her 2010 study, Herringin states that; the design and operation of the humanitarian aid chain will play an important role in achieving a rapid, effective, and efficient response. Among these, several factors affect the success of a humanitarian supply chain. Researchers have tried to discover the success factors among the processes related to the humanitarian supply chain and introduce them to managers and decision-makers in this field. Therefore, it is important to identify the most important factors for the success of the humanitarian chain and relief logistics in the management of these processes. Knowing the interrelationships between success factors is very essential and helps managers and decision-makers to pay more attention to key factors. Managers will also be able to identify key factors to strengthen them and spend their resources on factors that have been prioritized in the first place (Hosseini, 2008).

In the meantime, athletes, as well-known figures, can play an important role in the development of the humanitarian aid supply chain. In today's society, exercise is no longer viewed solely as a physical and mental activity for physical and mental health. Rather, many overt and covert economic and political relations have taken it away from its original purpose and made sport far beyond mere physical and mental activity. Given the large audience of sports and the pervasiveness of different types of sports for the majority of people in human society, it seems that in general, sports have strayed from their main purpose and has become a tool in the 
hands of governments to create some social, political and economic activities (Brown et al., 2003).

Sports and championship games are popular and popular ways to entertain and spend leisure time and play a special role in people's lives. It has been instilled since ancient times that; Famous heroes and athletes inspire confidence and success in the community. In any case, the new media creates famous athletes, and the person created by the media becomes a role model or a hero. Athletes are seen throughout commercials and on television. Everyone can see their image in stores and shopping malls to promote goods, they are brought in shows. Many columns and pages can be read about them in newspapers, and they can also be seen in movies. As a result, sports and famous athletes play a major role in society (Ghasemi, 2007).

Various studies have examined the factors affecting the humanitarian supply chain. Ghasemian et al. (2017) found in their research that factors such as continuous improvement in relief activities and strategic planning for relief logistics are at the highest level of priority over other factors. Van Wessen-hoo (2006) found that the model presented in this area includes five key elements in disaster preparedness, which are: Human resources, knowledge management, operations, and process management, financial resources, and effective results. Salehi and Khani (2017) pointed out that; having crisis management requires an efficient and coherent supply chain of actions and activities of all organizations involved in the crisis and the existence of a defect in any of the identified factors will lead to the disruption of the humanitarian supply chain. Yadav \& Barve (2015) noted that; Government policies, as well as organizational structure as critical success factors of the humanitarian supply chain, are identified as an important and fundamental issue. In their research, they found that; Government and organizational structure will play an important role in the growth and development of the humanitarian supply chain due to their profound impact. Ghasemian and Nowruzian (2015) after their studies found that; Factors such as continuous improvement in relief activities and strategic planning for relief logistics are at the highest level of priority over other factors. Gupta et al. (2017) also found that; Research in the field of a humanitarian supply chain is at a low level, this shows the lack of research in this area and the research gap.

Examining the theoretical foundations and research conducted in this field, it can be stated that; the humanitarian supply chain has always been studied in various researches; however, the use of athletes as important elements of this chain has not been studied in research. This has led to an understanding of the lack of operational strategies to benefit athletes in the humanitarian supply chain. Some recent incidents in Iran indicate that the country's top athletes have great potential to help in times of crisis. However, there were irregularities in this, which indicated that it was important for athletes to have a high potential to help the government and the people in times of crisis and on the other hand, the existence of a public order to guide these aids to increase productivity is essential.

The growing popularity of athletes in the national arena has led to their potential in the field of charity. The trust that people in the community have in popular athletes creates the potential to implement a humanitarian aid supply chain. This has led to athletes being cited as actual potentials for implementing the humanitarian aid supply chain. Considering the functions of popular athletes in this field but the lack of comprehensive and practical research has led to a lack of planning in this field can be seen. On the other hand, the lack of comprehensive research and, as a result, the lack of comprehensive planning to benefit popular athletes to develop the humanitarian aid supply chain, has led to targeted efforts in this area in the event of accidents and problems and practically the existing potentials in this field should not be exploited. The occurrence of these problems has caused the present study to be designed and implemented to investigate the factors affecting the development of the humanitarian aid supply chain by popular athletes. Therefore, the main question of the present study is; what are the factors influencing the development of the humanitarian aid supply chain by popular athletes? 


\section{Methodology}

The present study is one of the mixed researches which were done in the form of qualitative and quantitative methods. The present study is one of the applied researches. The method of data collection in the present study was a field. The statistical population of the present study in the qualitative section includes elites and experts in the field of the humanitarian supply chain, sports sociology, sports management, and crisis management. The sampling method in the qualitative part was purposeful. For this purpose, 13 elites and experts were selected as a research sample in the qualitative section. Also, in the quantitative part of the present study, in addition to the elites in the field of the humanitarian supply chain, sports sociology, sports management, and crisis management, some experts of the Crisis Management Organization and popular athletes were added to the statistical community.

Popular athletes included athletes who took part in the Kermanshah earthquake in 1397 with their physical presence and collecting public donations. After the investigations, the number of these people was 159 . Using the sampling method, the total number of all these individuals was identified as the research sample. After distributing and collecting the questionnaires, 107 completed questionnaires were collected. To distribute the questionnaires, the method of sending the questionnaire in person, e-mail, and cyberspace was used. Table 1 shows the population and statistical sample in quantitative sections of the research.

\section{Table 1}

Society and a statistical sample of research

\begin{tabular}{ccc}
\hline Groups & $\begin{array}{c}\text { Statistical } \\
\text { Society }\end{array}$ & Sample \\
\hline $\begin{array}{c}\text { Elites in the field of the humanitarian supply chain, sports } \\
\text { sociology, sports management, and crisis management }\end{array}$ & 62 & 48 \\
\hline Experts of the Crisis Management Organization & 55 & 42 \\
\hline Popular athletes & 42 & 17 \\
\hline Total & 159 & 107 \\
\hline
\end{tabular}

The collection tool of the present study in the qualitative section is a semi-structured interview. Also, according to the interviews, factors were identified that were used as research tools in the quantitative section. The questionnaire was divided into two general sections: demographic characteristics and its questions, which were in the form of five Likert options (from strongly agree to strongly disagree) and in 25 questions. These questions include 5 factors including managerial factors (questions 1 to 8), human factors (questions 9 to 12), cultural factors (questions 13 to 16), communication and technological factors (questions 17 to 23), and legal factors (questions 24 and 25). ) Were examined. The reliability of this questionnaire was confirmed by calculating Cronbach's alpha in all components as well as the general questionnaire. The overall reliability of this questionnaire was determined to be 0.84 . The reliability of the measurement model was evaluated by factor load coefficients and combined reliability, information about it was provided in the research findings section.

The content validity of this questionnaire was assessed using the opinions of 10 university professors. Also, regarding the content validity, the content validity index CVI and the content validity ratio CVR of the content validity and the use of formulas related to these methods were confirmed by using validity forms. The content validity ratio according to the number of professors (10 people) was 0.99 and the content validity index was 0.99 . Therefore, the content validity of the research tool was confirmed. Also, the construct validity of the questionnaire was evaluated using confirmatory factor analysis. Therefore, according to the results obtained in the reliability and validity of the questionnaire, it can be stated that the questionnaire of the present study had good reliability and validity. The results related to the 
validity and reliability of the research are shown in Table 4. Also, in the quantitative analysis part of the research, the structural equation method with the PLS approach has been used.

\section{Results}

Descriptive findings related to the statistical samples of the present study are shown in Table 2 .

Table 2

Descriptive research findings

\begin{tabular}{|c|c|c|c|c|}
\hline & $\begin{array}{l}\text { Demographic } \\
\text { characteristics }\end{array}$ & Groups & Frequency & Percent \\
\hline \multirow{4}{*}{$\begin{array}{c}\text { The } \\
\text { qualitative } \\
\text { part of the } \\
\text { research }\end{array}$} & \multirow[t]{2}{*}{ Gender } & Man & 10 & 77 \\
\hline & & Female & 3 & 23 \\
\hline & \multirow[b]{2}{*}{ Level of Education } & P.H.D & 11 & 84 \\
\hline & & Masters & 2 & 13.5 \\
\hline \multirow{9}{*}{$\begin{array}{l}\text { The } \\
\text { quantitative } \\
\text { part of the } \\
\text { research }\end{array}$} & \multirow[b]{2}{*}{ Gender } & Man & 92 & 86 \\
\hline & & Female & 15 & 14 \\
\hline & \multirow{3}{*}{ Level of Education } & P.H.D & 55 & 51.5 \\
\hline & & Masters & 33 & 30.8 \\
\hline & & $\begin{array}{l}\text { Bachelor and } \\
\text { lower }\end{array}$ & 19 & 17.7 \\
\hline & \multirow[t]{4}{*}{ Ages } & Under 30 years & 5 & 4.7 \\
\hline & & $30-40$ years & 38 & 35.5 \\
\hline & & $40-50$ years & 42 & 39.2 \\
\hline & & Over 50 years & 22 & 20.6 \\
\hline
\end{tabular}

The descriptive results of the research showed that; Samples of the qualitative part of the study included $77 \%$ male and $23 \%$ female. Also, among these research samples, people with doctoral degrees have the highest number with $84.5 \%$. Descriptive results related to the gender status of the research sample in the present quantitative section showed that; $86 \%$ of the participants in the study are men and $14 \%$ are women. The results of descriptive research findings also showed that; among the research samples, people with doctoral degrees have the highest number with $51.5 \%$. The descriptive results of the research also showed that; among the age groups, the age group of $40-50$ years with $39.2 \%$ has the highest number. To identify the factors affecting the development of the humanitarian aid supply chain by popular athletes, the opinions of experts in the form of a qualitative method were used. After coding, the features extracted from the interviews were identified. Table 3 shows the qualitative results of the present study.

Table 3

Open and axial coding 


\begin{tabular}{|c|c|}
\hline Categories & Extracted features \\
\hline Management factors & $\begin{array}{l}\text { - Support of the country's senior sports managers } \\
\text { - Existence of appropriate procedures in attracting athletes to } \\
\text { the humanitarian aid chain } \\
\text { - Existence of departments and evaluation committees on } \\
\text { how athletes enter and perform in the humanitarian aid } \\
\text { chain } \\
\text { - Existence of short-term and long-term programs in } \\
\text { attracting athletes to the humanitarian aid chain } \\
-\quad \text { Establish evaluation and monitoring of the effectiveness of } \\
\text { athletes in times of crisis } \\
-\quad \text { Making group decisions with athletes in times of crisis } \\
-\quad \text { Establishing facilities for the presence and stay of athletes } \\
\text { in times of crisis } \\
-\quad \text { Identify the areas and areas required for the activities of } \\
\text { athletes in times of crisis }\end{array}$ \\
\hline Human Factors & $\begin{array}{l}\text { - } \\
\text { Educate athletes on how to work in times of crisis } \\
\text { Establish associations and legal associations of athletes to } \\
\text { improve their presence in times of crisis } \\
\text { - Upgrading athletes' technical knowledge about activities in } \\
\text { times of crisis } \\
\text { - Set clear tasks for athletes in times of crisis }\end{array}$ \\
\hline cultural factors & $\begin{array}{l}\text { - Provide training to athletes on the importance and how to } \\
\text { enter the humanitarian aid chain } \\
\text { - Improving the motivation of athletes to participate in the } \\
\text { humanitarian supply chain } \\
\text { - Reflecting the positive behaviors and activities of athletes in } \\
\text { times of crisis through the national media } \\
\text { - Increasing the scope of athletes' independence for presence } \\
\text { and activity in times of crisis }\end{array}$ \\
\hline $\begin{array}{l}\text { Communication } \\
\text { and } \\
\text { technological } \\
\text { factors }\end{array}$ & $\begin{array}{l}\text { - Improve organizational communication with popular } \\
\text { athletes } \\
\text { - Creating an appropriate organizational structure in times of } \\
\text { crisis to cooperate and coordinate with popular athletes } \\
-\quad \text { Create databases of popular athletes seeking activity in } \\
\text { times of crisis } \\
-\quad \text { Creating appropriate information technologies for athletes } \\
\text { in times of crisis } \\
-\quad \text { Involve athletes in terms of their abilities in times of crisis } \\
-\quad \text { Announcing public and specific needs to athletes in times of } \\
\text { crisis through public media } \\
-\quad \text { Maintain and improve communication infrastructure in } \\
\text { times of crisis to communicate with athletes }\end{array}$ \\
\hline Legal factors & $\begin{array}{l}\text { - Reducing legal barriers to the presence of athletes in times } \\
\text { of crisis } \\
\text { - Creating a legal framework for selecting athletes to be used } \\
\text { in times of crisis }\end{array}$ \\
\hline
\end{tabular}

Qualitative results of the research showed that; 25 micro actives were extracted through interviews, these factors were divided into 5 categories: cultural, managerial, legal, human, and communication-technological factors. To investigate these factors, quantitative structural equations were performed. Therefore, first, the Smirnov Clomograph test examined the normal 
state of the research data distribution. The results of the above test showed that; the level of significance in all factors was lower than 0.05 , which indicates that the research data is abnormal, for this purpose, non-parametric statistics were used to analyze the data of the present study. Figures 1 and 2 show the measurement model and the degree of significant coefficients of $\mathrm{t}$, the factors affecting the development of the humanitarian aid supply chain by popular athletes.

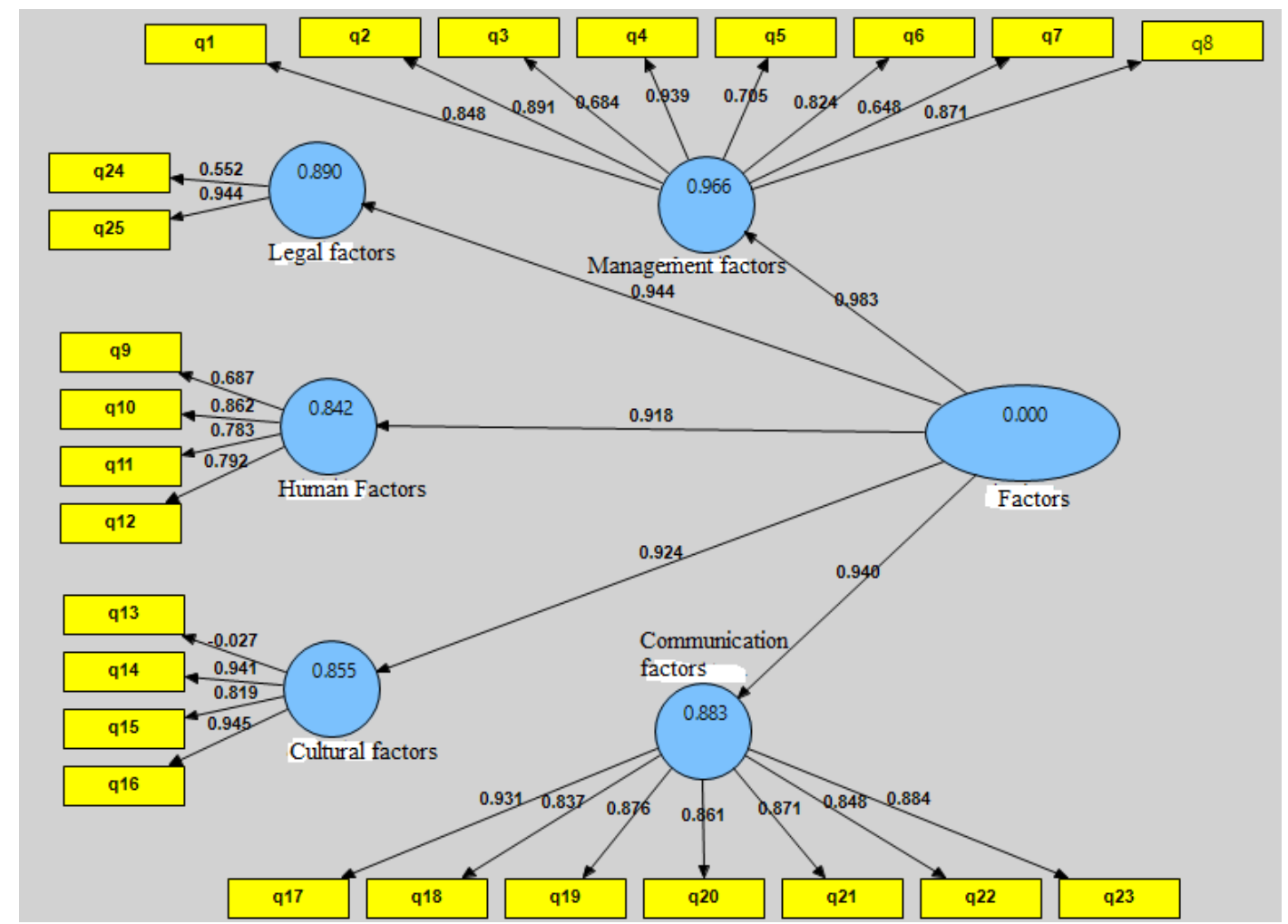

Figure 1

A model for measuring the factors affecting the development of the humanitarian aid supply chain by popular athletes 


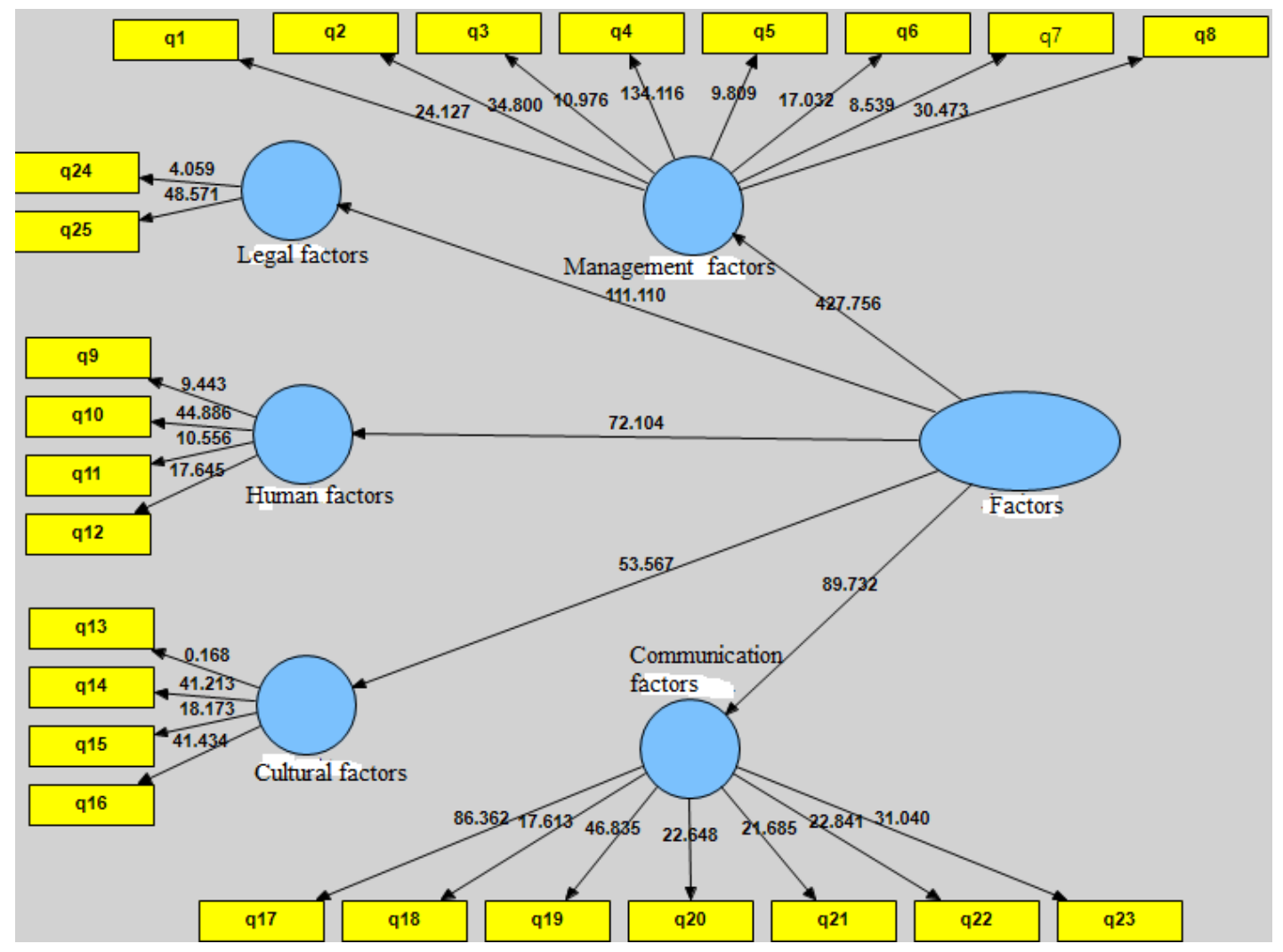

Figure 2

Significant coefficients of $\mathrm{T}$ factors affecting the development of the humanitarian aid supply chain by popular athletes

Table 4 summarizes the measurement models and significance coefficients of $\mathrm{t}$ factors affecting the development of the humanitarian aid supply chain by popular athletes.

\section{Table 4}

Summary of statistical results of factors affecting the development of the humanitarian aid supply chain by popular athletes

\begin{tabular}{ccc}
\hline Factors & T & impact \\
\hline Management factors & 427.756 & 0.983 \\
\hline cultural factors & 53.567 & 0.924 \\
\hline Human Factors & 72.104 & 0.918 \\
\hline Legal factors & 111.110 & 0.944 \\
\hline Facility-technological factors & 89.732 & 0.940 \\
\hline
\end{tabular}

The research results showed that; among the factors affecting the development of the humanitarian aid supply chain by popular athletes, managerial factors had the most role and importance $($ impact $=0.983 ; \mathrm{T}$-factor $=427.756$ ). 
To evaluate the report of the present research model, the fit indices related to the structural equation method with the PLS approach were used. Table 5 shows the results related to the fit indices of the above model.

\section{Table 5}

Fitting Indicators of Factors Affecting the Development of the Humanitarian Aid Supply Chain by Popular Athletes

\begin{tabular}{cccccc}
\hline & $\begin{array}{c}\text { Management } \\
\text { factors }\end{array}$ & $\begin{array}{c}\text { cultural } \\
\text { factors }\end{array}$ & $\begin{array}{c}\text { Human } \\
\text { Factors }\end{array}$ & $\begin{array}{c}\text { Legal } \\
\text { factors }\end{array}$ & $\begin{array}{c}\text { Facility- } \\
\text { technological } \\
\text { factors }\end{array}$ \\
\hline $\begin{array}{c}\text { Cronbach's } \\
\text { alpha }\end{array}$ & 0.85 & 0.79 & 0.89 & 0.82 & 0.86 \\
\hline $\begin{array}{c}\text { Combined } \\
\text { reliability }\end{array}$ & 0.72 & 0.62 & 0.78 & 0.69 & 0.67 \\
\hline $\begin{array}{c}\text { Convergent } \\
\text { validity }\end{array}$ & 0.57 & 0.62 & 0.69 & 0.58 & 0.60 \\
\hline $\mathrm{R}^{2}$ & 0.966 & 0.855 & 0.842 & 0.890 & 0.883 \\
\hline $\mathrm{Q}^{2}$ & 0.417 & 0.410 & 0.398 & 0.510 & 0.436 \\
\hline $\mathrm{GOF}$ & 0.587 & 0.629 & 0.674 & 0.598 & 0.637 \\
\hline
\end{tabular}

The results of the research fit indices showed that; the value of Cronbach's alpha and the combined reliability of the factors in all 5 factors are higher than 0.7, which indicates the appropriate reliability of the model. The results also showed that; the degree of convergent validity for all factors is above the standard level of 0.4, which indicates the appropriateness of the degree of convergent validity of the research. Also, divergent validity in the present study was examined and confirmed in the form of a factor matrix in factors. Also, according to Figure 1, all factor loads related to research factors are more than 0.4, which indicates the appropriateness of this criterion.

Given the three values of $0.19,0.33$, and 0.67 which are introduced as weak, medium, and strong values for R2 and in all factors, a value greater than 0.33 was obtained, which indicates the appropriateness of this index. Given the three values of $0.02,0.15$, and 0.32 which are introduced as weak, medium, and strong values for Q2, in all factors, a value greater than 0.36 was obtained, which indicates the appropriateness of this index. Given the three values of 0.01, 0.25 , and 0.36 which are introduced as weak, medium, and strong values for GOF, in all factors, a value greater than 0.36 was obtained, indicating a strong overall fit of the model, with this in mind, it was found that the model presented in the present study has a good fit.

\section{Discussion and conclusion}

The research results showed that; Factors affecting the development of the humanitarian aid supply chain through popular athletes include transient factors including managerial factors, cultural factors, human factors, legal factors, and facilities-technological factors. The diverse nature of these factors indicates that; To develop the supply chain of humanitarian aid through popular athletes, it is necessary to pay attention to a set of conditions and factors, which raises the importance of the supply chain of humanitarian aid through popular athletes and also the existence of problems in this area. The variety of identification factors indicates the importance of; To develop the supply chain of humanitarian aid through popular athletes, large and 
comprehensive programs are needed that can overshadow all the dimensions involved in the supply chain of humanitarian aid through popular athletes. Salehi and Khani (2017) in their research pointed out that; Some factors related to human, managerial, evaluation, cultural, quality, strategy, and logistics issues play an important role in improving the humanitarian supply chain. With this in mind, it can be stated that; the factors identified in the present study are similar to the factors identified in Salehi and Khani (2017) in some factors. Dubey and Gunasekaran (2016) noted in their study that; Agility, adaptability, and coordination as important pillars of the humanitarian supply chain play an important role in improving and expanding the sustainability of the humanitarian supply chain. However; the factors identified in the present study and the study of Dubey and Gunasekaran (2016) are inconsistent due to cultural and social differences in the study environment of the present study and the study of Dubey and Gunasekaran (2016). The diverse nature of the factors identified for the development of the humanitarian aid supply chain by popular athletes shows that; Attention to all available dimensions is essential to strengthening the presence of athletes in the humanitarian supply chain. The present study also showed that; all identified factors play a significant role in the development of the humanitarian aid supply chain by popular athletes. The results of the present study showed that; among these, managerial factors are most used to develop the supply chain of humanitarian aid through popular athletes. Yadav and Barvi (2015) were among the studies that indicated that management factors play an important role in improving the humanitarian supply chain. Van Wassenhove (2006) also found that; Management factors as one of the important and basic principles of effective disaster management using the humanitarian supply chain.

It seems that the managerial agents, by creating the basic infrastructure for the development of the supply chain of humanitarian aid through popular athletes, will cause this chain to meet its other needs as well. In other words, the moving wheel of the humanitarian aid supply chain through popular athletes is management agents. These factors, by making initial efforts at the level of organizations in charge of sports affairs and crisis management, cause some ambiguities in this area to be resolved, in other words, to properly cover the programs related to this chain. It is, therefore, suggested that; To have appropriate procedures in attracting athletes to the humanitarian aid chain and also to identify these athletes and invite them before the crisis occurs and coordinate with them; Take full advantage of the help of these athletes in the event of a possible crisis. It is also suggested that by creating sports associations for the supply chain of humanitarian aid by athletes to regulate and legalize the actions of athletes in times of crisis.

The use of popular athletes due to their high influence in the social arena can have a higher executive guarantee in the implementation of the humanitarian supply chain. Creating management platforms to familiarize athletes with the humanitarian supply chain and increase their awareness in this area can have a profound impact on the development of the humanitarian aid supply chain through popular athletes. Popular athletes must use their abilities and potentials to play a key role in controlling and managing the crisis. On the other hand, the existence of some problems and inconsistencies regarding the assistance of popular athletes and other people in times of crisis in some recent events in the country shows that it is important that; The mechanism of the supply chain of humanitarian aid through popular athletes should be implemented more regularly to take advantage of all the potentials of athletes, to reduce some of the irregularities formed in this area.

\section{References}


Barani, R., Sadeghi, M. R., \& Safari, H. (2017). Identifying the dimensions and performance indicators of the humanitarian supply chain (earthquake specific case) and determining the relationships between them. Crisis Prevention and Management Knowledge, 7(1), 9-24.

Brown, W., Basil, M., \& Bocarnea, M. (2003). The influence of famous athletes on health beliefs and practices. Journal of Health Communication, 8, 41-57.

Cozzolino, A. (2012). Humanitarian Logistics and Supply Chain Management. Humanitarian Logistics, 6(4), 5-17. https://doi.org/10.1007/978-3-642-30186-5

Dubey, R., \& Gunasekaran, A. (2016). The sustainable humanitarian supply chain design: agility, adaptability and alignment. International Journal of Logistics Research and Applications, 19(1), 62-82.

Gupta, S., Altay, N., \& Luo, Z. (2017). Big data in humanitarian supply chain management: a review and further research directions. Annals of Operations Research, 12, 1-21.

Hosseini, M. (2008). Crisis Management. Tehran Crisis Prevention and Management Organization.

Jahre, M. (2017). Humanitarian supply chain strategies-a review of how actors mitigate supply chain risks. Journal of Humanitarian Logistics and Supply Chain Management, 7(2), $82-101$.

Kabra, G., Ramesh, A., \& Arshinder, K. (2015). Identification and prioritization of coordination barriers in humanitarian supply chain management. International Journal of Disaster Risk Reduction, 13, 128-138.

Qasemi, H. (2007). The role of mass media in the development of sports in the country, $\mathrm{PhD}$ thesis, Tehran: Islamic Azad University, Science and Research Branch.

Qasemian Sahebi, S., \& Nowruzian, J. (2015). Identifying and Prioritizing Key Success Factors in the Humanitarian Supply Chain Using Interpretive Structural Modeling (ISM) Approach, First International Conference on Management, Economics, Accounting and Educational Sciences, Sari, Ayandeh Saz Research and Consulting Company, Payame Noor Neka University.

Salehi Tadi, E., \& Khani, N. (2016). Factors of Cohesion of Humanitarian Supply Chains in Natural Crises. Quarterly Journal of Crisis Prevention and Management, 7(2), 139-129.

Schulz, S. F., \& Heigh, I. (2009). Logistics performance management in action within a humanitarian organization. Management Research News 32(11):1038-1049. https://doi.org/10.1108/01409170910998273

Seifert, L., Kunz, N., \& Gold, S. (2018). Humanitarian supply chain management responding to refugees: a literature review. Journal of Humanitarian Logistics and Supply Chain Management, 9, 239-255.

Van Wassenhove, L. N. (2006). Humanitarian aid logistics: supply chain management in high gear. Journal of the Operational Research Society, 57(5), 475-489.

Yadav, D. K., \& Barve, A. (2015). Analysis of critical success factors of humanitarian supply chain: An application of Interpretive Structural Modeling. International journal of disaster risk reduction, 12, 213-225. 